\title{
STRATEGI BERARGUMENTASI KOLABORATIF BERPENDEKATAN SAINTIFIK DENGAN MEDIA DEORAWA UNTUK MENINGKATKAN KOMPETENSI SISWA SMP MENYIMPULKAN PIKIRAN DAN PENDAPAT NARASUMBER
}

\author{
Narimo \\ omnarimo@yahoo.co.id \\ STKIP PGRI Trenggalek
}

\begin{abstract}
Abstrak. Penelitian ini bertujuan untuk meningkatkan kompetensi siswa SMP menyimpulkan pikiran dan pendapat narasumber melalui strategi berargumentasi kolaboratif berpendekatan saintifik dengan media deorawa. Data penelitian dikumpulkan melalui instrumen lembar penilaian unjuk kerja, lembar observasi, dan jurnal harian terhadap subjek penelitian sejumlah 26 siswa kelas VII SMP Negeri 3 Watulimo Kabupaten Trenggalek, Provinsi Jawa Timur. Data yang terkumpul, khususnya data verbal, dianalisis secara kualitatif dengan analisis interaktif model Miles dan Huberman. Hasil penelitian adalah peningkatan kompetensi menyimpulkan pikiran dan pendapat narasumber, yang mencakup kemampuan menyusun terma, premis minor, premis mayor, dan simpulan.
\end{abstract}

Kata Kunci: argumentasi kolaboratif, pendekatan saintifik, media deorawa, penyimpulan pikiran dan pendapat

Abstract. This study to improve competence of Junior High School students in compile conclusions the thoughts and opinions of the interviewees through strategy of collaborative argumentation scientifically approach with deorawa media. Research data collected through performance assessment sheet instrument, observation sheet, and daily journal toward research subject of 26 students of class VII SMP Negeri 3 Watulimo Trenggalek, East Java. The collected data, especially verbal data, was analyzed qualitatively by interactive analysis of Miles and Huberman models. The result of the research is the improvement of the competence to compile conclusions the thoughts and opinions of the interviewees, which includes the ability to compile the term, the minor premise, the major premise, and conclusions.

Keywords: collaborative argumentation, scientific approach, deorawa media, inferences of thoughts and opinions

\section{PENDAHULUAN}

Kompetensi menyimpulkan pikiran dan pendapat narasumber jika dirinci lebih lanjut sebenarnya terbagi menjadi dua, yaitu (1) kompetensi menyimpulkan pikiran narasumber dan

kompetensi menyimpulkan pendapat narasumber. Dalam Kamus Besar Bahasa Indonesia (2008), pikiran diartikan sebagai hasil berpikir, yaitu hasil menggunakan akal budi untuk mempertimbangkan dan memutuskan sesuatu; sedangkan pendapat diartikan sebagai kesimpulan yang diperoleh sesudah mempertimbangkan, menyelidiki, dan sebagainya. Dengan demikian, untuk menyimpulkan pikiran dan pendapat seseorang memerlukan suatu proses.

Proses penyimpulan pikiran dan pendapat dilakukan sebagai upaya untuk mendapatkan simpulan yang sahih berdasarkan pada premis yang relevan. Tindak menghubungkan premis dengan simpulan itu disebut penalaran. Sebuah konstruksi yang terbangun atas seperangkat premis yang mendukung simpulan dengan penalaran yang logis disebut argumen. Argumen logis jika terma, premis, dan simpulannya memenuhi hukum-hukum logika. Dengan kata lain, argumen dikatakan logis jika pada setiap tataran kebahasaan memenuhi sistem logikanya masing-masing, baik pada tataran frasa (struktur grup), tataran klausa, maupun tataran wacana (Halliday, 2004:310; Santoso, 2011:7).

Selanjutnya, proses menghasilkan argumen itu disebut argumentasi. Argumentasi memiliki pengertian yang dekat dengan argumen, bahkan karena dekatnya, ada yang menyamakannya (Sidharta, 2010:7). Meskipun demikian, pada prinsipnya pengertian argumentasi berbeda dengan argumen. Masalahnya, argumentasi merupakan aktivitas atau upaya untuk meyakinkan pendengar atau pembaca, 


\section{Narimo \\ STRATEGI BERARGUMENTASI KOLABORATIF \\ BERPENDEKATAN SAINTIFIK DENGAN MEDIA DEORAWA \\ UNTUK MENINGKATKAN KOMPETENSI SISWA SMP MENYIMPULKAN PIKIRAN DAN PENDAPAT NARASUMBER}

sedangkan argumen sebagai sarana yang digunakan untuk meyakinkannya. Agak berbeda dengan pengertian tersebut, Warnich dan Inch (1994:10) memberikan batasan argumentasi sebagai proses pembuatan argumen untuk membenarkan keyakinan, sikap, dan nilai-nilai sehingga dapat memengaruhi orang lain. Sebagai sebuah proses, berargumentasi dapat dilatihkan atau diajarkan.

Bagi siswa SMP khususnya siswa kelas VII, pembelajaran berargumentasi bukan pembelajaran yang mudah karena merupakan pembelajaran berbasis penalaran. Dalam pembelajaran ini siswa harus dapat menyusun fakta (evidensi) sebagai landasan menyusun simpulan. Untuk itu, sejalan dengan karakteristik siswa, pembelajaran berargumentasi di SMP direkomendasikan untuk dilaksanakan secara kolaboratif (Narimo, 2015:285). Di samping itu, pembelajaran ini akan relevan jika didekati dengan pendekatan saintifik (pendekatan ilmiah) sebab di dalam pendekatan tersebut pembelajaran ditekankan pada penalaran, baik penalaran induktif (inductive reasoning) maupun penalaran deduktif (deductive reasoning). Penalaran deduktif melihat fenomena umum kemudian menarik simpulan yang spesifik. Sebaliknya, penalaran induktif memandang fenomena spesifik kemudian menarik simpulan umum (Kemendikbud, 2015:25).

Dalam hal penyimpulan ini, fakta di lapangan membuktikan bahwa pada umumnya siswa SMP banyak mengalami kesulitan. Fakta tersebut diperoleh penulis dari hasil pembelajaran yang dilakukan penulis di kelas VII-A SMP Negeri 3 Watulimo, Kabupaten Trenggalek, Provinsi Jawa Timur semester 2 tahun pelajaran 2018/2019 kepada 26 siswa. Pembelajaran ini mengangkat kompetensi dasar 9.1 Menyimpulkan pikiran atau gagasan dan pendapat seorang tokoh narasumber yang disampaikan dalam wawancara. Kesulitan tersebut terjadi baik pada aspek penyimpulan pikiran narasumber maupun aspek penyimpulan pendapat narasumber. Kesulitan siswa pada aspek penyimpulan pikiran narasumber terjadi ketika siswa menyusun terma, menyusun premis minor, menyusun premis mayor, dan menyusun simpulan pikiran narasumber. Kesulitan siswa pada aspek penyimpulan pendapat narasumber adalah ketika siswa menyusun terma, menyusun premis minor, menyusun premis mayor, dan menyusun simpulan pendapat narasumber. Kesulitan ini dapat dicermati pada ketuntasan hasil belajar siswa sebagai berikut. Pada aspek penyimpulan pikiran narasumber tuntas 10 siswa dengan persentase 38,5\%. Pada aspek penyimpulan pendapat narasumber tuntas 4 siswa dengan persentase $15,4 \%$. Sementara itu, secara total tuntas 5 siswa dengan persentase $19,2 \%$. Meskipun pembelajaran tersebut dilaksanakan secara kelompok, tetapi dalam pelaksanaannya kurang kolaboratif karena dari enam kelompok, yang kolaboratif hanya satu kelompok saja dengan persentase $16,7 \%$.

Sebagai upaya mengatasi masalah tersebut, penulis menggunakan strategi berargumentasi kolaboratif (strategi sikola) dengan pendekatan saintifik. Dalam pembahasan ini, yang dimaksud dengan argumentasi kolaboratif adalah argumentasi yang melibatkan beberapa peserta tutur (PT). Secara spesifik, argumentasi ini mengandung tiga unsur, yaitu (1) aktivitas pembentukan dan penggunaan argumen, (2) strategi dilakukan dengan bekerja sama beberapa PT, dan (3) tujuan untuk memengaruhi dan meyakinkan audiensi. Sementara itu, yang dimaksud dengan pendekatan saintifik (pendekatan ilmiah) adalah pendekatan berbasis proses keilmuan. Dalam pendekatan ini, proses pembelajaran disusun dengan urutan yang logis melaui proses (1) mengamati, (2) menanya, (3) mengumpulkan informasi /mencoba, (5) menalar/mengasosiasi, dan (6) mengomunikasikan.

Agar materi pembelajaran menarik dan sejalan dengan pola pikir anak, digunakanlah media deorawa (video wawancara siswa). Deorawa ini dirancang dan dilakukan oleh siswa dalam kelompokkelompok belajar kecil dari suatu kelas dengan anggota empat atau lima anak. Dengan strategi dan media ini, siswa dapat menyimpulkan pikiran dan pendapat narasumber dengan valid. Akhirnya, prestasi siswa mengalami peningkatan.

Berdasarkan permasalahan tersebut dilaksanakanlah penelitian tindakan kelas dengan judul Strategi Berargumentasi Kolaboratif Berpendekatan Saintifik dengan Media Deorawa untuk Meningkatkan Kompetensi Menyimpulkan Pikiran dan Pendapat Narasumber dalam Wawancara Siswa Kelas VII SMP Negeri 3 Watulimo Trenggalek. Dengan penelitian tersebut, peningkatan kompetensi menyimpulkan pikiran dan pendapat narasumber dapat dipaparkan secara lebih komprehensif. Dengan demikian, penelitian ini mempunyai dua tujuan, yaitu (1) meningkatkan kompetensi siswa dalam menyimpulkan pikiran narasumber dan (2) meningkatkan kompetensi siswa dalam menyimpulkan pendapat narasumber. 


\section{Narimo \\ STRATEGI BERARGUMENTASI KOLABORATIF \\ BERPENDEKATAN SAINTIFIK DENGAN MEDIA DEORAWA \\ UNTUK MENINGKATKAN KOMPETENSI SISWA SMP \\ MENYIMPULKAN PIKIRAN DAN PENDAPAT NARASUMBER}

\section{METODE PENELITIAN}

Penelitian ini didekati dengan pendekatan kualitatif. Pendekatan kualitatif dirumuskan oleh Bogdan dan Taylor (1975) sebagai prosedur penelitian yang menghasilkan data deskriptif berupa katakata tertulis atau lisan tentang orang-orang dan perilaku yang dapat diamati. Akan tetapi, untuk akurasi data, peneliti juga mendekatinya secara kuantitatif.

Penggunaan pendekatan ini dimaksudkan sebagai upaya untuk mengungkapkan permasalahan dan kondisi secara objektif berdasarkan data yang diperoleh, baik data verbal maupun data nonverbal. Dengan data yang lengkap dan akurat ini, diharapkan dapat diketahui secara pasti permasalahan yang dihadapi dan mampu memberikan perlakuan tindakan yang tepat.

Berhubung penelitian ini dilaksanakan bersama-sama dengan proses pembelajaran di kelas maka dirancang sebagai Penelitian Tindakan Kelas (PTK). Kemmis dan Taggart (1988:3) menyatakan bahwa PTK memiliki karakteristik (1) permasalahan diangkat dari dalam kelas tempat guru mengajar, (2) bersifat kolaboratif, dan (3) memunculkan adanya tindakan tertentu untuk memperbaiki proses belajar-mengajar di kelas. Tindakan tersebut dilaksanakan dalam proses pengkajian berdaur yang terdiri atas empat tahap, yakni (1) perencanaan, (2) tindakan, (3) observasi, dan (4) refleksi sebagaimana Gambar 1 berikut.

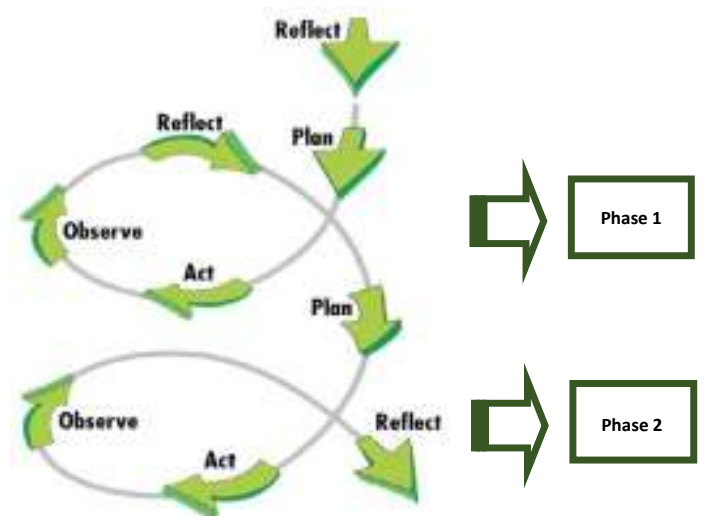

Gambar 1. Bagan Alur Penelitian Tindakan Kelas (Kemmis dan Taggart, 1988)

Terkait dengan alur tersebut, PTK ini dirancang sebanyak tiga fase, yaitu studi pendahuluan, siklus I, dan siklus II. Pada studi pendahuluan digunakan strategi sikola model belajar bersama (tanpa pembagian peran kolaborator) dengan perlakuan (1) mengamati dan menanyakan isi teks wawancara (tekwan) LKS, (2) mendata pernyataan narasumber (narsum) di tekwan LKS, (3) menalar pikiran dan pendapat narsum di tekwan LKS, dan (4) membacakan hasilnya di depan kelas. Pada siklus I digunakan strategi sikola model jigsaw kembar (kolaborator berperan sebagai tim ahli penyimpul pikiran dan tim ahli penyimpul pendapat) dengan perlakuan (1) mengamati dan menanyakan isi tekwan detu (deorawa tunggal), (2) mendata pernyataan narsum di detu, (3) menalar pikiran dan pendapat narsum di detu, dan (4) mempresentasikan hasilnya dengan plano. Pada siklus II digunakan strategi sikola model relasi intelektual (kolaborator berperan sebagai pengawal, penengah, dan penyimpul) dengan perlakuan(1) mengamati dan menanyakan isi tekwan dekel (deorawa kelompok), (2) mendata pernyataan narsum di dekel, (3) menalar pikiran dan pendapat narsum di dekel, dan (4) mempresentasikan hasilnya dengan LCD. Jika divisualisasikan, perbedaan perlakuan yang diberikan pada setiap fase penelitian itu adalah sebagaimana Gambar 2 berikut.

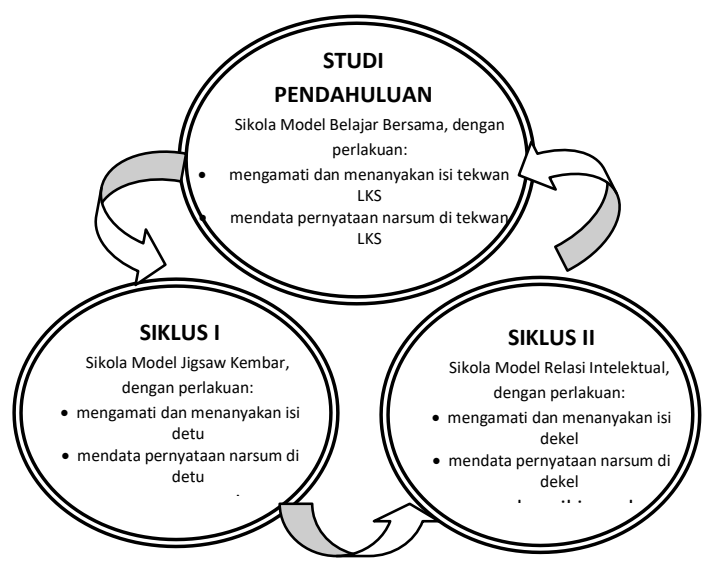

Gambar 2. Bagan Perlakuan Setiap Fase Penelitian

Berdasarkan hal itu, secara khusus pemilihan subjek penelitian ini didasarkan atas pertimbangan (1) peneliti sehari-hari bertugas mengajar di kelas itu, (2) kegiatan pembelajaran menyimpulkan pikiran dan pendapat narasumber mengalami kendala, dan (3) kompetensi siswa dalam menyimpulkan pikiran dan pendapat narasumber masih rendah. Agar data dari subjek penelitian dapat diperoleh dengan baik, diperlukan instrumen pengumpul data yang tepat.

Instrumen pengumpul data dalam penelitian ini ada beberapa macam, yaitu lembar penilaian unjuk kerja, lembar observasi, dan jurnal harian. Lembar penilaian unjuk kerja digunakan untuk meneliti hasil pembelajaran. Lembar observasi diperlukan untuk mengamati dan mencatat perilaku dan kejadian yang sebenarnya. Jurnal harian digunakan sebagai instrumen pendamping lembar penilaian unjuk kerja dan lembar observasi. Dalam jurnal harian ini peneliti membuat catatan 


\section{Narimo \\ STRATEGI BERARGUMENTASI KOLABORATIF \\ BERPENDEKATAN SAINTIFIK DENGAN MEDIA DEORAWA \\ UNTUK MENINGKATKAN KOMPETENSI SISWA SMP \\ MENYIMPULKAN PIKIRAN DAN PENDAPAT NARASUMBER}

secara rinci agar dapat mendeskripsikan situasi secara lengkap dan akurat.

Agar valid, instrumen dan data penelitian perlu divalidasi dengan beberapa jenis alat validasi sesuai dengan fungsinya masing-masing. Untuk memeriksa kembali data hasil observasi digunakan member check (Wiriatmadja, 2007:168). Untuk mencocokkan kembali data yang ditemukan dengan subjek yang diteliti digunakan validasi subjek dan validasi data yang disebut trianggulasi data (Elliott, 1991:101). Selanjutnya, untuk memastikan kebenaran proses dan hasil penelitian digunakan key respondents review (Hopkins, 1993:156) dengan meminta mitra peneliti yang banyak mengetahui PTK agar menjadi validator. Data yang telah divalidasi tersebut dilaporkan dalam bentuk pernyataan verbal, tabel, diagram, dan grafik. Dengan instrumen dan data yang valid diharapkan dapat mendukung keberhasilan penelitian.

Keberhasilan penelitian ini dapat dilihat dari peningkatan kompetensi menyimpulkan pikiran dan pendapat narasumber. Dari sudut pandang ini, pembelajaran dikatakan berhasil jika terdapat peningkatan proses dan hasil pembelajaran menyimpulkan pikiran dan pendapat narasumber pada siklus-siklus pembelajaran yang dilakukan. Setelah datadata diperoleh, selanjutnya ditelaah, diklasifikasi, diverifikasi, dan dianalisis.

Data verbal (kata-kata) dianalisis secara kualitatif dengan analisis interaktif model Miles dan Huberman (1994:12) yang mencakup empat tahap, yaitu (1) pengumpulan data, (2) reduksi data, (3) penyajian data, dan (4) penarikan simpulan/verifikasi. Data verbal ini diperoleh dari hasil kerja siswa di lembar penilaian unjuk kerja, hasil observasi kelompok, dan jurnal harian. Data tersebut digunakan untuk melukiskan dan menafsirkan keadaan yang ada dikaitkan dengan perkembangan argumentasi masingmasing kelompok.

Data nonverbal (angka-angka) dianalisis secara kuantitatif. Data ini bersumber dari hasil penilaian guru yang terdapat di dokumen lembar penilaian unjuk kerja. Peneliti menggunakan data ini untuk menentukan daya serap siswa sehingga dapat diketahui ketuntasan hasil belajar baik per aspek pembelajaran maupun secara total. Data yang telah dianalisis, lalu disimpulkan, dan diinterpretasikan. Jika dari hasil interpretasi ini kegiatan masih belum berhasil (belum memecahkan masalah yang ditetapkan), strategi pembelajaran tersebut perlu direvisi, selanjutnya menjadi perencanan pada siklus berikutnya.

\section{HASIL DAN PEMBAHASAN}

\section{Hasil Penelitian}

Hasil penelitian ini berupa paparan peningkatan kompetensi (1) menyimpulkan pikiran narasumber dan (2) menyimpulkan pendapat narasumber. Kedua hasil penelitian tersebut dapat dipaparkan per siklus sebagai berikut.

Pembelajaran pada siklus I dilaksanakan dalam dua pertemuan setiap pertemuan 2 jam pelajaran $(2 \mathrm{X}(2 \mathrm{X} 40$ menit)) dengan strategi sikola model jigsaw kembar dan perlakuan (1) mengamati dan menanyakan isi tekwan detu (deorawa tunggal), (2) mendata pernyataan narsum di detu, (3) menalar pikiran dan pendapat narsum di detu, dan (4) mempresentasikan hasilnya dengan plano. Dengan perlakuan seperti ini diperoleh hasil sebagai berikut.

Pada siklus I ini setiap kelompok sudah lancar dalam menyusun terma pikiran narasumber. Pikiran ini ditandai oleh pewatas (modifier) terma $\mathrm{M}$ yang menggambarkan keadaan pikiran narasumber, misalnya: tentu, pasti, tidak, tidak tahu, kurang, mungkin, kira-kira, dan kadang-kadang. Akan tetapi, ada kelompok yang mengalami kesulitan dalam mengklasifikasikan pikiran narasumber berdasarkan pewatas terma M-nya karena beranggapan bahwa pewatas kepastian itu hanya pasti dan tentu saja, padahal pada konteks tertentu jadi, memang, tidak, tidak mau, bukan juga dapat memarkahi kepastian (afirmasi atau negasi), asalkan didasari sikap tanpa keragu-raguan. Kelancaran menyusun terma ini memudahkan siswa dalam menyusun premis minor dan premis mayor.

Kecepatan dan kelancaran kerja kelompok terjadi ketika penyimpulan pikiran narasumber. Dengan adanya tim ahli penyimpul pikiran, pada siklus I ini siswa dapat menyimpulkannya dengan relatif cepat. Misalnya, ketika ditanya, "Biasanya, kapan Ibu mendapatkan pendapatan yang banyak?" Penjual nasi ikan bakar menjawab, "Ya... tentu... pada hari Minggu, tahun baru juga". Tim penyimpul pikiran Kelompok Kompas menulis premis minor "Penjual nasi ikan bakar menentukan bahwa pendapatannya banyak pada hari Minggu dan tahun baru", premis mayornya "Penjual nasi ikan bakar memastikan pendapatannya banyak pada hari Minggu dan tahun baru", dan simpulannya "Penjual nasi ikan bakar memastikan bahwa pendapatannya banyak pada hari Minggu dan tahun baru". Simpulan ini hasil reduplikasi dengan sedikit perubahan pada 


\section{Narimo \\ STRATEGI BERARGUMENTASI KOLABORATIF \\ BERPENDEKATAN SAINTIFIK DENGAN MEDIA DEORAWA \\ UNTUK MENINGKATKAN KOMPETENSI SISWA SMP \\ MENYIMPULKAN PIKIRAN DAN PENDAPAT NARASUMBER}

$\mathrm{M}$ premis dan simpulan sehingga tetap berstruktur S-M, bukan S-P. Jadi, penyimpulan tersebut tanpa menggunakan premis mayor yang berstruktur M-P. Jika dibagankan, penyimpulan itu adalah sebagai berikut.

Secara logika, penyimpulan ini mengandung kebenaran, tetapi tidak valid karena hanya memaparkan kembali premis minor sehingga tidak menggambarkan pikiran narasumber. Ketakvalidan itu digambarkan dengan garis putus-putus ( ) pada terma $\mathrm{S}$ premis mayor dan terma $\mathrm{M}$ pada simpulan yang semestinya keduaduanya berterma P. Agar valid, dibutuhkan premis mayor yang mampu menjembatani premis minor dan simpulan yang berstruktur M-P, misalnya "Penentuan bahwa pendapatannya banyak pada hari Minggu dan tahun baru merupakan kondisi pikiran kepastian" sehingga simpulannya "Penjual nasi ikan bakar memiliki kondisi pikiran kepastian". Dengan demikian, terkonstruksi argumen penyimpulan taklangsung.

Pada penyimpulan pendapat narasumber, siswa telah mampu menyusun terma pendapat narasumber dan menyusun premis minor dengan struktur S-M. Misalnya, ketika penjual pentol keliling ditanya "Berapa lama Bapak berjualan?", narasumber menjawab, "Ya, ndak mesti, pokoknya habis ya pulang", tim penyimpul pendapat Kelompok Tempo menulis premis minor "Berjualan sebagai penjual pentol keliling itu waktunya tidak pasti”.

Pre

Sim

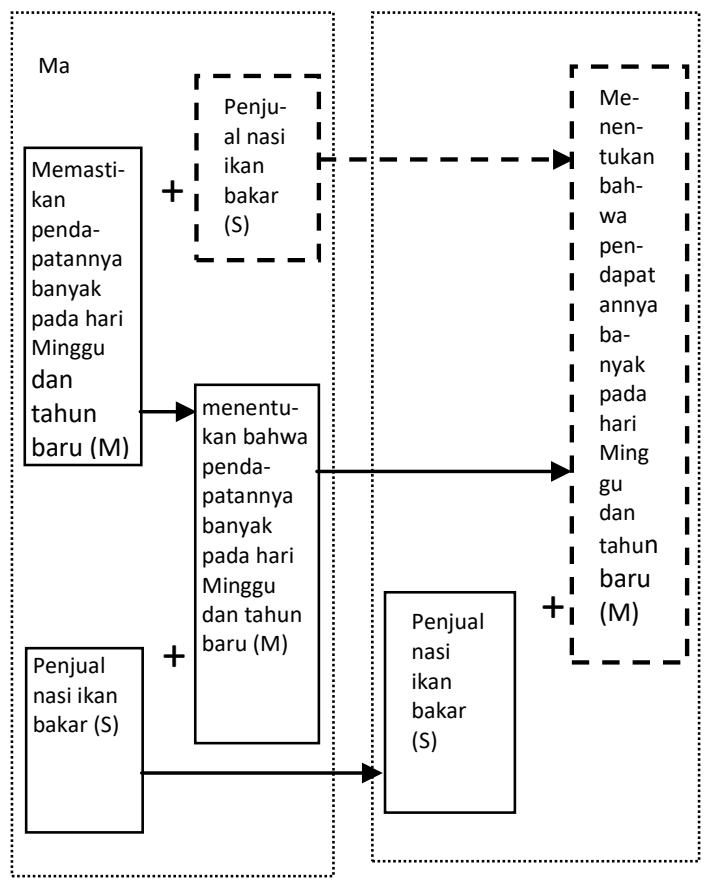

Ketika menyusun premis mayor, pada umumnya siswa belum mampu. Misalnya, berdasarkan premis minor tadi, tim penyimpul pendapat Kelompok Tempo menulis premis Kelompok Tempo menulis premis mayor "Waktunya tidak dapat dipastikan berjualan sebagai penjual pentol keliling". Ini bukan premis mayor, melainkan premis minor yang dikonversi (dibalik) dari struktur S-M menjadi M-S dengan sedikit perubahan redaksi pada $\mathbf{M}$ dengan isi sama (tidak pasti=tidak dapat dipastikan).

Dengan tidak adanya premis mayor yang mampu menjembatani premis minor dan simpulan, penyimpulan pendapat narasumber pada siklus I ini berbentuk penyimpulan langsung. Misalnya, berdasarkan premis di atas, tim penyimpul pendapat Kelompok Tempo menulis simpulan "Waktunya tidak dapat ditentukan berjualan sebagai penjual pentol keliling". Ini penyimpulan langsung dengan pola konversi yang dapat dibagankan sebagai berikut.

Berdasarkan hasil penelitian pada siklus I tersebut dapat diinterpretasikan bahwa (1) adanya tim ahli penyimpul pikiran dan penyimpul pendapat dengan tugas yang terpisah, kelompok masih kurang kolaboratif $(50 \%)$, (2) belum seluruh siswa tuntas belajar $(80,7 \%)$, dan (3) rata-rata siswa belum mampu menyusun premis mayor sehingga simpulannya tidak valid. Oleh sebab itu, penelitian ini perlu dilanjutkan ke siklus II.

Pembelajaran pada siklus II juga dilakukan selama dua pertemuan setiap

$$
\text { Pre Sim }
$$

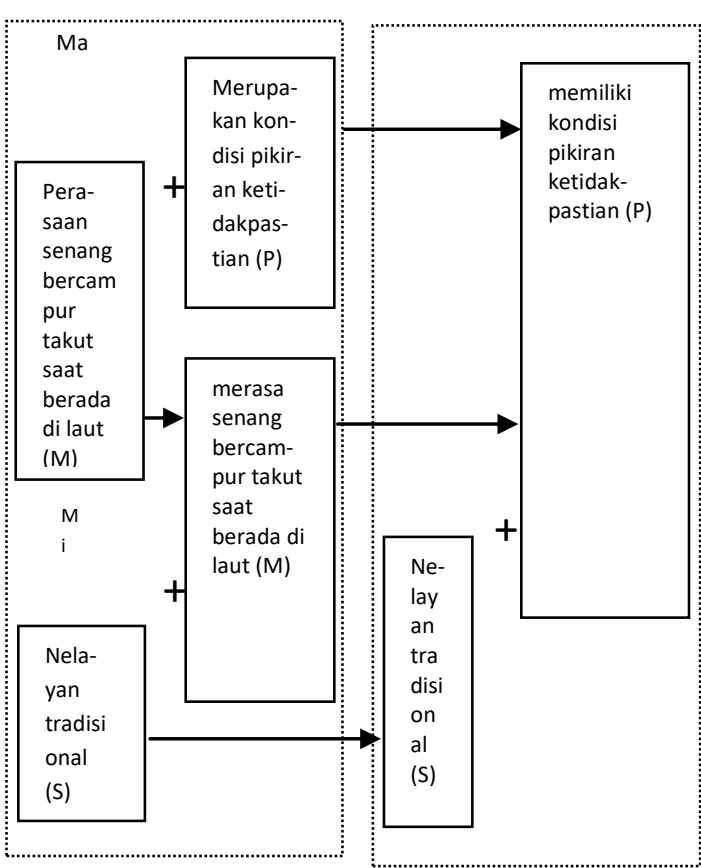

pertemuan 2 jam pelajaran $(2 \times(2 \times 40$ menit)) dengan strategi sikola model relasi intelektual dan perlakuan (1) mengamati dan menanyakan isi tekwan dekel (deorawa 


\section{Narimo \\ STRATEGI BERARGUMENTASI KOLABORATIF \\ BERPENDEKATAN SAINTIFIK DENGAN MEDIA DEORAWA \\ UNTUK MENINGKATKAN KOMPETENSI SISWA SMP \\ MENYIMPULKAN PIKIRAN DAN PENDAPAT NARASUMBER}

kelompok), (2) mendata pernyataan narsum di dekel, (3) menalar pikiran dan pendapat narsum di dekel, dan (4) mempresentasikan hasilnya dengan LCD. Dengan perlakuan seperti ini diperoleh hasil sebagai berikut.

Dengan adanya kolaborator pengawal, penengah, dan penyimpul, pada siklus II ini setiap kelompok telah mampu menyimpulkan pikiran narasumber. Pada aspek ini, siswa telah mampu menyusun terma, menyusun premis minor, menyusun premis mayor, serta menyusun simpulan pikiran narasumber sehingga terbangun penyimpulan taklangsung dengan pola silogisme.

Kompetensi siswa pada aspek penyimpulan pikiran di siklus II in ' digambarkan sebagai berikut. Mi ketika nelayan tradisional ditanya, "Bagaimana perasaan Anda setelah berada di tengah-tengah laut?", ia menjawab, "Ya, senanglah jadi seorang nelayan ...," dan ketika ditanya, "Apakah tidak merasa takut saat berada di laut?", ia menjawab, "Takut sih, tapi cuma sebentar." Berdasarkan hal ini, siswa menyusun terma yang berkaitan dengan pikiran narasumber "ketidakpastian pikiran" sehingga pengawal Kelompok Jawa Pos menulis premis minor "Nelayan tradisional merasa senang bercampur takut saat berada di laut", penengah menulis premis mayor "Perasaan senang bercampur takut saat berada di laut merupakan kondisi pikiran ketidakpastian", dan penyimpul menyimpulkannya "Nelayan tradisional memiliki kondisi pikiran ketidakpastian". Bagan penyimpulan itu adalah sebagai berikut.

Pre

Sim

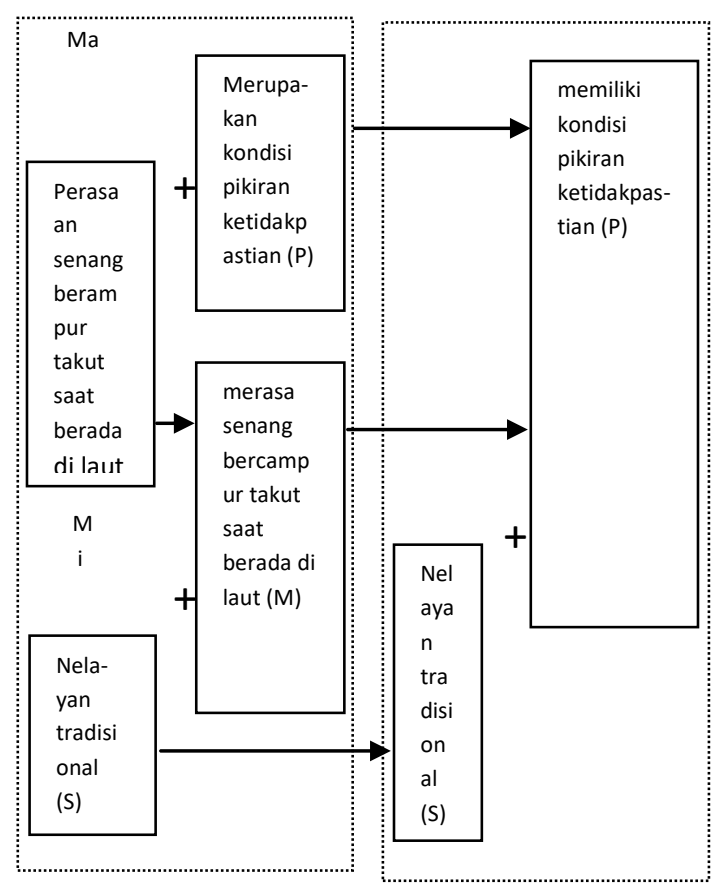

Penyimpulan tersebut valid. Validitas simpulan itu didasari pada proses penyimpulan yang berlandaskan premis minor dan premis mayor sehingga menghasilkan simpulan pikiran narasumber yang bersrtuktur S-P.

Kemampuan siswa menyimpulkan pendapat narasumber pada siklus II dapat dijelaskan sebagai berikut. Misalnya, ketika ditanya, "Berapa banyak ikan yang dapat Anda tangkap?", nelayan tradisional menjawab, "Ya ndak tentu, misalnya lima kilo, enam kilo"; dan ketika ditanya, "Apakah pernah, melaut itu tidak menghasilkan uang?", narasumber menjawab, "Ya ... sering, sering". Berdasarkan hasil wawancara itu, siswa

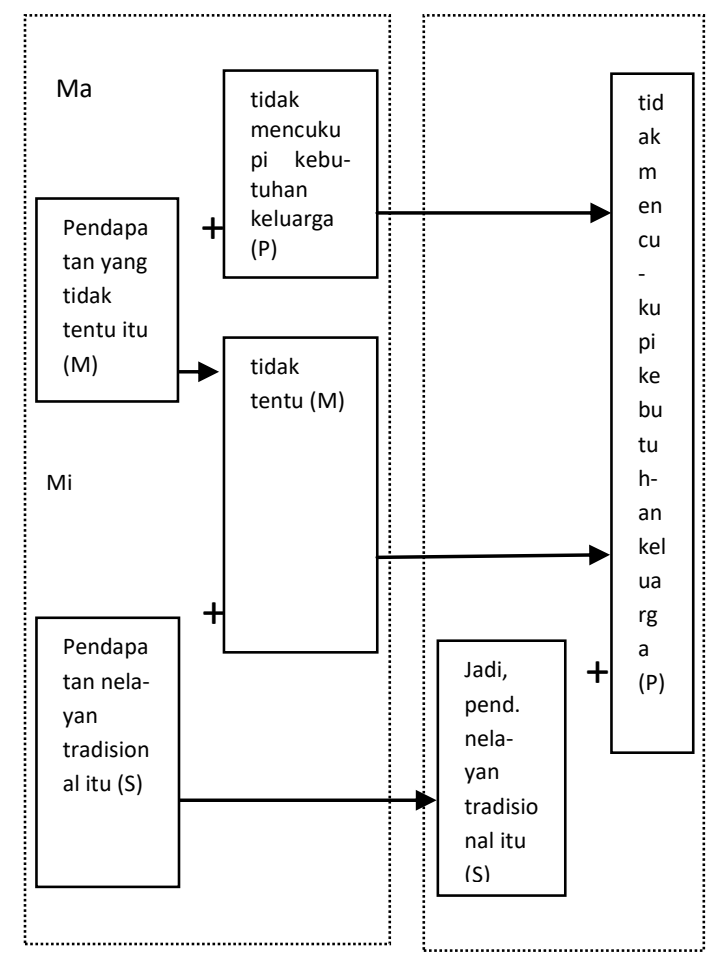

menyusun terma yang berkaitan dengan pendapat narasumber "Ketidakpastian pendapatan nelayan tradisional", pengawal Kelompok Jawa Pos menulis premis minor "Pendapatan nelayan tradisional itu tidak tentu", penengah menulis premis mayor "Pendapatan yang tidak tentu itu tidak mencukupi kebutuhan keluarga", dan penyimpul menulis simpulan pendapat narasumber "Jadi, pendapatan nelayan tradisional itu tidak mencukupi kebutuhan keluarga". Bagan penyimpulan ini sebagai berikut.

Penyimpulan argumen silogisme tersebut valid. Validitas argumen itu terbangun karena simpulannya berlandaskan pada premis minor, premis mayor, serta memaparkan pendapat narasumber sesuai premis-premis yang mendasarinya. 


\section{Narimo \\ STRATEGI BERARGUMENTASI KOLABORATIF \\ BERPENDEKATAN SAINTIFIK DENGAN MEDIA DEORAWA \\ UNTUK MENINGKATKAN KOMPETENSI SISWA SMP MENYIMPULKAN PIKIRAN DAN PENDAPAT NARASUMBER}

Berdasarkan hasil penelitian pada siklus II tersebut, dapat diinterpretasikan bahwa (1) dengan adanya anggota pengawal, penengah, dan penyimpul yang bekerja dalam kelompok secara utuh, semua kelompok telah kolaboratif (100\%), (2) hampir seluruh siswa tuntas belajar $(96,2 \%)$, dan (3) rata-rata siswa telah mampu menyusun terma, menyusun premis minor, menyusun premis mayor, dan mampu menyusun simpulan yang berkaitan dengan pikiran/pendapat narasumber secara valid. Oleh sebab itu, penelitian ini dapat diakhiri, dengan catatan seorang siswa yang belum tuntas perlu pembinaan secara khusus.

Peningkatan hasil penelitian ini akan lebih jelas baik berkaitan dengan kolaborasi kelompok maupun ketuntasan individual jika direkapitulasi menjadi satu kesatuan. Rekapitulasi atau gambaran secara utuh hasil penelitian ini dipaparkan denganTabel 1 berikut.

\section{Pembahasan}

Hasil penelitian sebagaimana telah dipaparkan, selanjutnya dibahas untuk menjawab masalah dan menafsirkan temuan penelitian. Pembahasan hasil penelitian ini dibagi menjadi dua. Kedua pembahasan itu adalah pembahasan (1) peningkatan kompetensi menyimpulkan pikiran narasumber dan (2) peningkatan kompetensimenyimpulkan pendapat narasumber.

\section{Peningkatan Kompetensi Menyimpulkan Pikiran Narasumber}

Sesuai tahapannya, peningkatan kompetensi siswa dalam menyimpulkan pikiran narasumber terbagi empat. Keempat peningkatan tersebut adalah peningkatan kemampuan (1) menyusun terma pikiran narasumber, (2) menyusun premis minor pikiran narasumber,

(3) menyusun primis mayor pikiran narasumber, dan (4) menyusun simpulan pikiran narasumber.

Peningkatan kemampuan siswa menyusun terma pikiran narasumber terjadi pada siklus I dan II. Pada siklus I siswa lancar dalam menyusun terma pikiran narasumber. Pernyataan ini ditandai oleh pewatas terma M, misalnya: tentu, pasti, tidak, tidak tahu, mungkin, kira-kira, bisa jadi, dan kadang-kadang. Pada siklus II siswa mampu mengklasifikasi terma tersebut berdasarkan keadaan pikirannya yang terdapat dalam terma $\mathrm{M}$, misalnya: ketidaktahuan, (2) kesangsian, (3) dugaan, dan (4) kepastian. Kondisi ini menggambarkan kemampuan menalar pada ranah logika frasa (struktur grup). Artinya, siswa dapat menalar hubungan makna head dan modifier (Halliday, 2004:310).

Peningkatan kemampuan siswa dalam menyusun premis minor pikiran narasumber terjadi pada siklus I dan II. Pada siklus I siswa mampu menyusun premis minor, meskipun kadang-kadang kurang logis dan belum mengarah pada pikiran narasumber, misalnya "Penjual nasi ikan bakar menentukan bahwa pendapatannya banyak pada hari Minggu dan tahun baru”. Pada siklus II siswa mampu menyusun premis minor dalam bentuk kalimat yang logis dengan struktur S-M (terma M tentang pikiran narasumber), misalnya "Nelayan tradisional merasa senang bercampur takut saat berada di laut". Kelogisan kalimat ini dipengaruhi oleh adanya deretan konstituen (unsur-unsur kalimat) yang mempunyai hubungan bernalar sehingga mudah dipahami dan dapat diterima dalam pertuturan (Soedjito dan Saryono, 2012:153). Sementara itu, Halliday (2004:310) memandang hal ini sebagai logika klausa, yaitu logika yang bekerja di dalam konstituen gramatikal.

Tabel 1. Rekapitulasi Hasil Penelitian

\begin{tabular}{|c|c|c|c|c|c|c|}
\hline \multirow{2}{*}{ Fase } & \multicolumn{3}{|c|}{$\begin{array}{l}\text { nurauviasi } \\
\text { Kelompok (\%) }\end{array}$} & \multicolumn{3}{|c|}{ 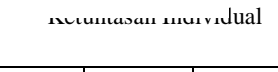 } \\
\hline & $\begin{array}{c}\text { Kura } \\
\text { ng } \\
\text { Kola } \\
\text { borat } \\
\text { if }\end{array}$ & $\begin{array}{c}\text { Kolabo } \\
\text { ratif }\end{array}$ & $\begin{array}{c}\text { Sang } \\
\text { at } \\
\text { Kola } \\
\text { borat } \\
\text { if }\end{array}$ & $\begin{array}{c}\text { Penyi } \\
\text { mpul } \\
\text { an } \\
\text { Pikir } \\
\text { an }\end{array}$ & $\begin{array}{l}\text { Penyim } \\
\text { pulan } \\
\text { Pendap } \\
\text { at }\end{array}$ & Total \\
\hline $\begin{array}{l}\text { Std. } \\
\text { Pend. }\end{array}$ & $\begin{array}{c}83,3 \\
\%\end{array}$ & $16,7 \%$ & $0 \%$ & $\begin{array}{c}38,5 \\
\%\end{array}$ & $15,4 \%$ & $\begin{array}{l}19,2 \\
\%\end{array}$ \\
\hline $\begin{array}{l}\text { Siklu } \\
\text { s I }\end{array}$ & $50 \%$ & $50 \%$ & $0 \%$ & $\begin{array}{c}84,6 \\
\%\end{array}$ & $76,1 \%$ & $\begin{array}{c}80,7 \\
\%\end{array}$ \\
\hline $\begin{array}{l}\text { Siklu } \\
\text { s II }\end{array}$ & $0 \%$ & $66,7 \%$ & $\begin{array}{c}33,3 \\
\%\end{array}$ & $100 \%$ & $88,5 \%$ & $\begin{array}{c}96,2 \\
\%\end{array}$ \\
\hline
\end{tabular}

dalam meningkatan kemampuan siswa narasumber terjadi pada siklus I dan II. Pada siklus I siswa mampu menyusun premis dengan makna setara premis minor. Akan tetapi, premis ini belum dapat disebut premis mayor karena tidak berstruktur M-P, misalnya "Penjual nasi ikan bakar memastikan pendapatannya banyak pada hari Minggu dan tahun baru". Pada siklus II siswa mampu menyusun premis mayor tentang pikiran narasumber, misalnya "Perasaan senang bercampur takut saat berada di laut merupakan kondisi pikiran ketidakpastian". Hal ini menggambarkan bahwa siswa mampu menghubungkan makna antarpremis (antraklausa) atau mampu menalar pada tataran logika wacana (Halliday, 2004:310).

Peningkatan kemampuan siswa dalam menyimpulkan pikiran narasumber 


\section{Narimo \\ STRATEGI BERARGUMENTASI KOLABORATIF \\ BERPENDEKATAN SAINTIFIK DENGAN MEDIA DEORAWA \\ UNTUK MENINGKATKAN KOMPETENSI SISWA SMP MENYIMPULKAN PIKIRAN DAN PENDAPAT NARASUMBER}

juga terjadi pada siklus I dan II. Pada siklus I siswa mampu menyusun simpulan pikiran narasumber dalam bentuk penyimpulan langsung dengan pola reduplikasi atau konversi. Penyimpulan ini menghasilkan simpulan yang takvalid karena tidak menggambarkan kondisi pikiran narasumber, misalnya "Penjual nasi ikan bakar memastikan bahwa pendapatannya banyak pada hari Minggu dan tahun baru". Kemampuan tersebut membuktikan bahwa pemikiran siswa lebih didominasi pada penalaran sederhana yang tidak valid (Poespoprodjo, 2007:191). Hal ini sejalan dengan pendapat Diezmann, Watters, dan English (2002:289) bahwa kemampuan anak untuk bernalar terbatas pada kemampuan yang dipengaruhi oleh pengetahuan dasar yang lemah. Sebaliknya pada siklus II, dengan diskusi yang intensif tersusunlah premis mayor berstruktur M-P. Fakta ini membuktikan bahwa dengan berlatih yang intensif dalam kelompok kolaboratif, siswa mampu menyusun simpulan pikiran narasumber dengan valid, misalnya "Nelayan tradisional memiliki kondisi pikiran ketidakpastian". Hal ini berarti bahwa siswa mampu membaca akal budi seseorang berdasarkan apa yang dikatakan atau dituturkannya dengan asumsi bahwa perkataan adalah ekspresi dari pikiran dan pikiran seseorang dapat diketahui dari perkataan (bahasanya) (Mundiri, 2010:9; Khalimi, 2011:40).

\section{Peningkatan Kompetensi Menyimpulkan Pendapat Narasumber}

Peningkatan kompetensi siswa dalam menyimpulkan pendapat narasumber terbagi menjadi empat. Keempat peningkatan tersebut adalah peningkatan kemampuan (1) menyusun terma pendapat narasumber, (2) menyusun premis minor pendapat narasumber, (3) menyusun primis mayor pendapat narasumber, dan (4) menyusun simpulan pendapat narasumber.

Peningkatan kemampuan siswa menyusun terma pendapat narasumber terjadi pada siklus I dan II. Pada siklus I siswa dapat menyusun terma yang berkaitan dengan pendapat narasumber. Terman ini ditandai dengan sinonimi head dan modifier-nya, misalnya terma dalam "Waktu berjualan saya ya ndak mesti”. Dengan terma ini, siswa menalar pendapat narasumber tentang waktu yang tidak pasti (ndak=tidak, mesti=pasti). Pada siklus II siswa mampu menganalisis beberapa frasa (terma) yang memiliki fungsi modifier sama. Misalnya, modifier negasi ndak pada "Ikan yang saya dapat ndak tentu" dan modifier negasi sering tidak pada "Melaut itu sering tidak menghasilkan uang". Pada dasarnya kedua terma tersebut mengarah pada pendapat yang sama, yaitu pekerjaan yang tidak menyenangkan. Artinya, siswa dapat menalar beberapa head yang berbeda dan modifier yang sama atau hampir sama (Halliday, 2004:310).

Peningkatan kemampuan siswa dalam menyusun premis minor pendapat narasumber terjadi pada siklus I dan II. Pada siklus I siswa mampu menyusun premis minor, meskipun kadang-kadang kurang logis atau tidak efektif, misalnya "Berjualan sebagai penjual pentol keliling itu waktunya tidak pasti". Premis ini dapat diubah menjadi kalimat efektif "Waktu berjualan penjual pentol keliling itu tidak pasti". Pada siklus II siswa mampu menyusun premis minor berstruktur S-M yang mampu mendukung simpulan dengan kalimat yang logis dan efektif, misalnya "Pendapatan nelayan tradisional itu tidak tentu". Fakta ini menandakan bahwa siswa mampu menalar pada tataran logika klausa (Halliday, 2004:310). Dalam proses bernalar, keberadaan premis minor dalam silogisme sangat penting. Oleh sebab itu, banyak silogisme didasari oleh premis minor saja yang disebut entimema (Sumaryono, 1999:108). Merujuk pada contoh premis minor di atas, sebenarnya tanpa premis mayor, siswa sudah dapat menyimpulkannya, misalnya "Pendapatan nelayan tradisional itu tidak mencukupi kebutuhan keluarga". 


\section{Narimo \\ STRATEGI BERARGUMENTASI KOLABORATIF \\ BERPENDEKATAN SAINTIFIK DENGAN MEDIA DEORAWA \\ UNTUK MENINGKATKAN KOMPETENSI SISWA SMP MENYIMPULKAN PIKIRAN DAN PENDAPAT NARASUMBER}

Peningkatan kemampuan siswa dalam menyusun premis mayor pendapat narasumber terjadi pada siklus I dan II. Pada siklus I siswa mampu menyusun premis dengan makna setara premis minor, misalnya "Waktunya tidak dapat dipastikan berjualan sebagai penjual pentol keliling". Akan tetapi, premis ini bukan premis mayor, melainkan premis minor yang dikonversi (strukturnya dibalik dari S-M menjadi M-S), yaitu "Berjualan sebagai penjual pentol keliling waktunya tidak dapat dipastikan". Pada siklus II siswa mampu menyusun premis mayor, misalnya "Pendapatan yang tidak tentu itu tidak dapat mencukupi kebutuhan keluarga". Hal ini menggambarkan bahwa siswa mampu menalar pada tataran logika wacana (Halliday, 2004:310). Kemampuan menalar itu membuktikan bahwa siswa dapat menyusun jaminan argumen. Jaminan itulah yang oleh Toulmin (1990:143) disebut sebagai premis universal. Menurut Toulmin (1990:132), argumen akan memiliki jaminan valid jika jaminan itu mampu berfungsi sebagai jembatan untuk membuat transisi dari data ke simpulan.

Peningkatan kemampuan siswa dalam menyimpulkan pendapat narasumber juga terjadi pada siklus I dan II. Pada siklus I siswa mampu menyusun simpulan pendapat narasumber berupa penyimpulan langsung dengan pola reduplikasi atau konversi. Penyimpulan ini menghasilkan simpulan takvalid karena tidak menggambarkan pendapat narasumber, misalnya "Waktunya tidak dapat ditentukan berjualan sebagai penjual pentol keliling". Kemampuan siswa ini membuktikan bahwa penalaran siswa lebih didominasi oleh penalaran sederhana yang takvalid. Hal ini sejalan dengan pendapat Diezmann, Watters, dan English (2002:289) bahwa kemampuan anak bernalar terbatas pada kemampuan yang dipengaruhi oleh pengetahuan dasar yang lemah. Sebaliknya pada siklus II, dengan diskusi yang intensif tersusunlah premis mayor berstruktur M-P. Hal ini membuktikan bahwa dengan latihan intensif dalam kelompok kolaboratif, siswa mampu menyusun simpulan pendapat narasumber dengan valid, misalnya "Jadi, pendapatan nelayan tradisional itu tidak mencukupi kebutuhan keluarga". Kemampuan ini sebagai bukti bahwa siswa mampu menyusun argumen penyimpulan taklangsung silogisme karena mengandung simpulan dari premis minor dengan pertolongan premis perantara (Poespoprodjo dan Gilarso, 2006:124). Misalnya, premis minor "Pendapatan nelayan tradisional itu tidak tentu"; premis mayor "Pendapatan yang tidak tentu itu tidak mencukupi kebutuhan keluarga"; dan simpulannya "Pendapatan nelayan tradisional itu tidak mencukupi kebutuhan keluarga". Silogisme ini valid karena telah memenuhi sahnya silogisme, yaitu adanya tiga terma ( $\mathrm{S}, \mathrm{M}$, dan P) yang terdistribusi pada premis dan simpulan, serta adanya tiga keputusan, yaitu mayor, minor, dan simpulan (Hadi,

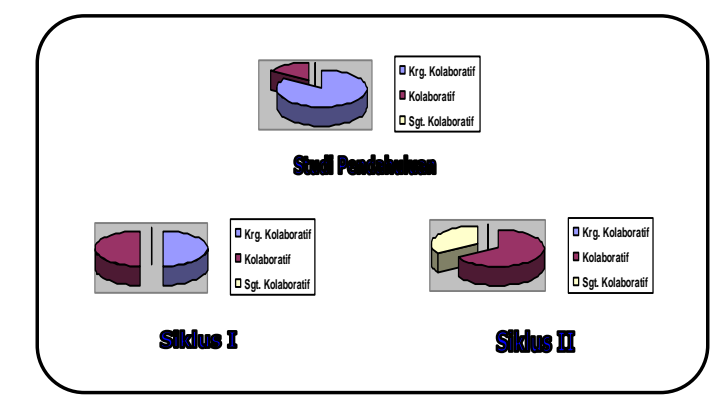

Gambar 3. Diagram Peningkatan Kolaborasi Kelompok Siswa

2008:62). Silogisme yang valid dengan struktur yang lengkap ini pada dasarnya sebagai wacana yang koheren dan kohesif (Alwi, dkk., 2003:427-435).

Dengan berakhirnya pembelajaran sampai siklus II, terlihatlah peningkatan proses kolaborasi dan kompetensi menyimpulkan pikiran dan pendapat narasumber. Peningkatan proses kolaborasi itu tampak pada Gambar 3 sebagai berikut.

Peningkatan kolaborasi kelompok tersebut juga diikuti oleh peningkatan ketuntasan hasil belajar siswa di semua aspek dan di setiap fase penelitian. Secara visual, peningkatan ketuntasan hasil belajar ini tampak pada Gambar 4 berikut.

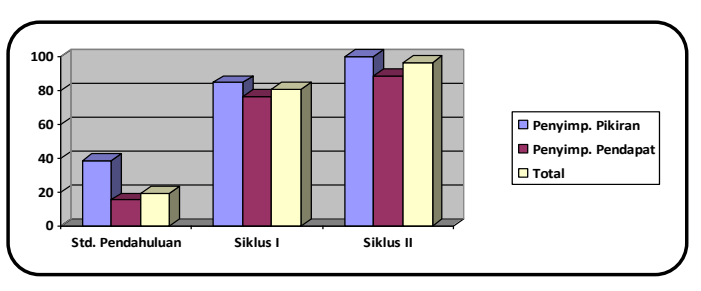

Gambar 4. Grafik Peningkatan Ketuntasan Hasil Belajar Siswa (dalam Persen)

\section{SIMPULAN}

Simpulan penelitian ini didasarkan pada rumusan masalah dan hasil penelitian, yaitu peningkatan kompetensi menyimpulkan pikiran narasumber dan peningkatan kompetensi menyimpulkan pendapat narasumber sebagai berikut.

Pertama, penerapan strategi berargumentasi kolaboratif berpendekatan Pada aspek ini, siswa mampu (1) menyusun 


\section{Narimo \\ STRATEGI BERARGUMENTASI KOLABORATIF \\ BERPENDEKATAN SAINTIFIK DENGAN MEDIA DEORAWA \\ UNTUK MENINGKATKAN KOMPETENSI SISWA SMP \\ MENYIMPULKAN PIKIRAN DAN PENDAPAT NARASUMBER}

terma, (2) menyusun premis minor, (3) menyusun premis mayor, dan (4) menyusun simpulan pikiran narasumber dengan ketuntasan belajar pada studi pendahuluan tuntas 10 anak $(38,5 \%)$, siklus I tuntas 22 anak $(84,6 \%)$, dan siklus II tuntas 26 anak $(100 \%)$.

Kedua, penerapan strategi berargumentasi kolaboratif berpendekatan saintifik dengan media deorawa ini mampu meningkatkan kompetensi siswa dalam menyimpulkan pendapat narasumber. Pada aspek ini, siswa mampu (1) menyusun terma, (2) menyusun premis minor, (3) menyusun premis mayor, dan (4) menyusun simpulan pendapat narasumber, dengan ketuntasan belajar pada studi pendahuluan tuntas 4 anak $(15,4 \%)$, siklus I tuntas 19 anak $(76,1 \%)$, dan siklus II tuntas 23 anak $(88,5 \%)$.

Simpulan umum penelitian ini adalah peningkatan kompetensi berargumentasi secara deduktif dengan pola silogisme. Kompetensi ini didukung oleh data ketuntasan belajar siswa pada aspek penyimpulan pikiran narasumber tuntas 26 anak (100\%), penyimpulan pendapat narasumber tuntas 23 anak $(88,5 \%)$, dan secara total tuntas 25 anak $(96,2 \%)$.

\section{SARAN}

Berdasarkan hasil penelitian tentang peningkatan kompetensi menyimpulkan pikiran dan pendapat narasumber tersebut, setidak-tidaknya disampaikan dua saran. Kedua saran tersebut adalah sebagai berikut.

Pertama, guru Bahasa Indonesia disarankan agar sering memberi kesempatan berargumentasi kepada siswa baik berargumentasi secara lisan maupun tulis. Pelatihan ini dapat dilakukan dengan sering berdiskusi dalam memecahkan masalah untuk mengambil sebuah simpulan.

Kedua, guru SMP disarankan agar dalam proses pembelajaran berpendekatan saintifik dengan media yang dikenal anak atau media berbasis lingkungan. Pendekatan dan media ini dapat mamacu anak untuk berpikir secara ilmiah atau bernalar baik secara deduktif maupun induktif.

\section{DAFTAR PUSTAKA}

Alwi, Hasan; Dardjowidjojo, Soenjono; Lapoliwa, Hans; dan Moeliono, Anton M. 2003. Tata Bahasa Baku Bahasa Indonesia. Jakarta: Pusat Bahasa dan Balai

Halliday, M. A. K. 2004. An Introduction to Functional Grammar. London: Hodder Arnold
Hopkins, D. 1993. Teacher's Guide to Classroom Research. Scond Edition. Philadelpia: Open University Press

Kemendikbud. 2015. Materi Pelatihan Guru Implementasi Kurikulum 2013 Tahun 2015 SMP/MTs Mata Pelajaran Bahasa Indonesia. Jakarta: BPSDM Dikbud dan PMP

Kemmis, S. dan Taggart, R. M. 1988. The Action Research Planner. Deakin University, Australia: Deakin University opress (3rd edition)

Khalimi. 2011. Logika: Teori dan Aplikasi. Jakarta Selatan: Gaung Persada Press

Miles, M.B. dan Huberman, A. M. 1994. Qualitative Data Analysis: An Expanded Sourcebook. Thousand Oaks: Sage

Mundiri. 2010. Logika. Jakarta: Raja Grafindo Persada

Narimo. 2015. Proposisi dan Argumen dalam Diskusi Kelas Siswa SMP. Jurnal Pendidikan Humaniora Vol. 3 No. 4 Hal. 276-286 Desember 2015.

Poespoprodjo, W. dan Gilarso, T. 2006. Logika Ilmu Menalar: Dasar-Dasar Berpikir Tertib, Logis, Kritis, Analitis, Dialektis. Bandung: Pustaka Grafika

Santosa, Riyadi. 2011. Logika Wacana: Analisis Hubungan Konjungtif dengan Pendekatan Linguistik Sistemik Fungsional. Surakarta: LPP UNS dan UNS Press 